\title{
Research Article: Effect of long term fertilization on soil nitrogen dynamics and balance in an irrigated inceptisol under finger millet-hybrid maize cropping sequence
}

\section{口 PRAGYAN PARAMITA ROUT, N. CHANDRASEKARAN, K. RULMOZHISELVAN AND DHANESHWAR PADHAN}

Article Chronicle: Received :

17.07.2017;

Accepted :

01.08.2017

KEY WORDS:

FYM, Hybrid maize, Integrated nutrient management,

Nitrogen dynamics, $\mathrm{N}$ fractions

Author for correspondence :

\section{PRAGYAN PARAMITA} ROUT

Department of Soil Science and Agricultural Chemistry, Tamil Nadu Agricultural University, COIMBATORE (T.N.) INDIA Email: parimita.pragyan $00 @$ gmail.com
SUMMARY : A field study was conducted in the year 2013-14 at TNAU, Coimbatore as a part of ongoing AICRP-LTFE to assess the effect of long-term fertilization on soil nitrogen (N) dynamics, $\mathrm{N}$ uptake and yield of hybrid maize under finger millet-hybrid maize cropping sequence. There were ten treatments each replicated four times in Randomized Block Design viz., $\mathrm{T}_{1}-50 \% \mathrm{NPK}, \mathrm{T}_{2}-100 \%$ NPK, $\mathrm{T}_{3}-150 \% \mathrm{NPK}, \mathrm{T}_{4}-100 \% \mathrm{NPK}$ + hand weeding, $\mathrm{T}_{5}-100 \% \mathrm{NPK}+\mathrm{ZnSO}_{4}, \mathrm{~T}_{6}-100 \% \mathrm{NP}, \mathrm{T}_{7}-100 \% \mathrm{~N}$ alone, $\mathrm{T}_{8}-100 \%$ NPK + FYM, $\mathrm{T}_{9}-100 \%$ NPK $(-\mathrm{S})$ and $\mathrm{T}_{10}-$ Absolute control. Results showed a significant higher value of available $\mathrm{N}$ in soil under $100 \% \mathrm{NPK}+\mathrm{FYM}$ treatment irrespective of critical growth stages of hybrid maize. Among $\mathrm{N}$ fractions, inorganic fractions viz., $\mathrm{NH}_{4}-\mathrm{N}, \mathrm{NO}_{3}-\mathrm{N}$ and fixed $\mathrm{NH}_{4}-\mathrm{N}$ were significantly affected by the incremental addition of $\mathrm{N}$. Integration of organics with inorganic fertilizers had a complementary effect on all fractions of nitrogen. Grain and straw yield of hybrid maize were significantly higher under $100 \%$ NPK + FYM treatment which showed a yield increase of $12.6 \%$ over 100\% NPK alone. Hence, integrated nutrient management (100\% NPK $+10 \mathrm{t} \mathrm{FYM} \mathrm{ha-1})$ has maximized yield of hybrid maize and improved the soil $\mathrm{N}$ pools by facilitating $\mathrm{N}$ transformation in soil.

How to cite this article : Rout, Pragyan Paramita, Chandrasekaran, N. Rulmozhiselvan, K. and Padhan, Dhaneshwar (2017). Effect of long term fertilization on soil nitrogen dynamics and balance in an irrigated inceptisol under finger millet-hybrid maize cropping sequence. Agric. Update, 12(TECHSEAR-6) : 1475-1483; DOI: 10.15740/HAS/AU/12. TECHSEAR(6)2017/1475-1483. 